\title{
The genus Stachybotrys (anamorphic fungi) in the semi-arid region of Brazil
}

\author{
TASCIANO DOS SANTOS SANTA IZABEL ${ }^{1}$, ALISSON CARDOSO RODRIGUES DA CRUZ ${ }^{1}$ \\ FLÁVIA RODRIGUES BARBOSA ${ }^{1}$, SHEILA MIRANDA LEÃO FERREIRA ${ }^{1}$, \\ MARCOS FÁBIO OLIVEIRA MARQUES ${ }^{2}$ and LUÍS FERNANDO PASCHOLATI GUSMÃO',
}

(received: May 20, 2009; accepted: August 12, 2010)

\begin{abstract}
The genus Stachybotrys (anamorphic fungi) in the semi-arid region of Brazil). Stachybotrys is characterized by macronematous, mononematous, unbranched or branched conidiophores, with discrete terminal and phialidic conidiogenous cells, and aseptate, reniform, ellipsoidal to spherical, smooth or verrucose conidia, which are produced in a slimy mass. Eight species have been reported from Brazil, occurring in the soil, air and leaf litter. During investigation of conidial fungi on decaying leaf litter in semi-arid areas of Brazil nine species were found: S. bisbyi (Sriniv.) G.L. Barron, S. chartarum (Ehrenb.) S. Hughes, S. globosa P. C. Misra \& S. K. Srivast., S. kampalensis Hansf., S. longispora Matsush., S. nephrospora Hansf., $S$. nilagirica Subram., Stachybotrys parvispora S. Hughes and S. verrucispora Matsush. Stachybotrys nilagirica is a new record from Brazil. Descriptions, comments, geographic distribution and illustrations are presented for above mentioned species. A key for all species recorded in semi-arid region of Brazil is presented.
\end{abstract}

Key words - conidial fungi, Memnoniella, taxonomy

RESUMO - (O gênero Stachybotrys (fungos anamórficos) na região semi-árida do Brasil). Stachybotrys é caracterizado por apresentar conidióforos macronemáticos, mononemáticos simples ou ramificados, células conidiogênicas evidentes, terminais e fialídicas e conídios asseptados, reniformes, elipsóides a esféricos, lisos ou verrucosos, produzidos em mucilagem. No Brasil já foram relatadas oito espécies, ocorrendo no solo, no ar e em material vegetal em decomposição. Durante investigação de fungos conidiais associados à serapilheira em áreas do semi-árido brasileiro foram encontradas nove espécies: $S$. bisbyi (Sriniv.) G.L. Barron, S. chartarum (Ehrenb.) S. Hughes, S. globosa P. C. Misra \& S. K. Srivast., S. kampalensis Hansf., S. longispora Matsush., S. nephrospora Hansf., S. nilagirica Subram., S. parvispora S. Hughes e S. verrucispora Matsush., dentre estas S. nilagirica constitui um novo registro para o Brasil. Descrições, comentários, distribuição geográfica e ilustrações são apresentadas para as espécies citadas. Chave de identificação para as espécies registradas no Brasil é apresentada.

Palavras-chave - fungos conidiais, Memnoniella, taxonomia

\section{Introduction}

The genus Stachybotrys Corda is worldwide in distribution although some species are restricted to the tropics and subtropics (Pinruan et al. 2004). The genus was erected for a single species Stachybotrys atra (Corda 1837), and it is characterized by macronematous, monomenatous, single or branched conidiophores, with discrete phialidic conidiogenous cells, and 0 -septate conidia, produced in a slimy mass, usually appearing dark in colour (Jong \& Davis 1976, Mercado-Sierra et al. 1997).

The genus has been subject to controversy since it was proposed (Li \& Yang 2005). Corda (1837) described

1. Universidade Estadual de Feira de Santana, Departamento de Ciências Biológicas, Laboratório de Micologia, Av. Transnordestina, s/n, Novo Horizonte, 44036-900 Feira de Santana, BA, Brazil.

2. Universidade do Estado da Bahia, Campus VII, Departamento de Educação, Laboratório de Microbiologia, Rodovia Lomanto Júnior, BR 407 km 127, 48970-000 Senhor do Bonfim, BA, Brazil.

3. Corresponding author: lgusmao@uefs.br the conidia as 2-celled, but up to the present, all accepted members of Stachybotrys produce unicellular conidia (Jong \& Davis 1976). After re-examining the type material of $S$. atra, Hughes (1958) recombined it as $S$. chartarum (Ehrenb.) S. Hughes.

Stachybotrys and Memnoniella Höhn have been considered distinct genera (Ellis 1971, 1976, Jong \& Davis 1976). However, members of Stachybotrys and Memnoniella are morphologically and physiologically closely related (Jong \& Davis 1976). The main difference between these two genera is that the conidia are in long dry chains in Memnoniella while they form slimy masses in Stachybotrys (Jong \& Davis 1976). Smith (1962) and Carmichael et al. (1980) have considered this is not a valid generic distinction and have suggested the two genera be combined under the older name of Stachybotrys. Following phylogenetic and morphological analyses, Haugland et al. (2001) considered Memnoniella echinata (Rivolta) Galloway and M. subsimplex (Cooke) Deighton to be better placed as Stachybotrys echinata (Rivolta) G. Sm and S. subsimplex Cooke. The four remaining 
species of Memnoniella should probably be transferred to Stachybotrys, following molecular analysis (Pinruan et al. 2004).

Many species of Stachybotrys are commonly found in soil and are capable of utilizing cellulose and damaging fabric made of plant fibers (Jong \& Davis 1976). Stachybotryotoxicosis is a disease of farm animals, particularly of horses, caused by $S$. chartarum. It has increasingly attracted public attention to its effect on human health following reports of its association with idiopathic pulmonary hemorrhage in infants (Dearborn et al. 1999). Subsequently, this species was reportedly isolated for the first time from the lung of a child diagnosed with pulmonary hemosiderosis (Elidemir et al. 1999).

More than 50 species are accepted in the genus (Pinruan et al. 2004). However, only eight species are reported for semi-arid region of Brazil: S. bisbyi (Sriniv.) G.L. Barron and S. kampalensis Hansf. (Marques et al. 2007); S. chartarum (Ehrenb.) S. Hughes (as S. atra var. cylindrospora (C.N. Jensen) Rayss \& Borut) (Batista \& Upadhyay 1965); S. globosa P.C. Misra \& S.K. Srivast. and S. verrucispora Matsush. (Leão-Ferreira et al. 2008); S. longispora Matsush. (Castañeda-Ruiz et al. 2003); S. nephrospora Hansf (Gusmão et al. 2006; Barbosa et al. 2008) and S. parvispora S. Hughes (Barbosa et al. 2009).

Stachybotrys atra var. cylindrospora was reported from semi-arid region by Batista \& Upadhyay (1965), however, $\operatorname{Li}$ (2007) after reexamining the type material of S. cylindrospora and S. atra var. cylindrospora concluded that these taxa are synonymous of $S$. chartarum.

Stachybotrys alternans Bonord. was reported from semi-arid region but was not accepted in the review by Pinruan et al. (2004) and is not included in the following key.

\section{Materials and methods}

During several expeditions from 2000 to 2007 in areas of semi-arid Caatinga biome, at the state of Bahia, Ceará, Pernambuco and Rio Grande do Norte, in Northeast region of Brazil, samples of leaf litter were collected, placed in separate paper bags and taken to the laboratory. The samples were washed and incubated in moist chambers consisting of Petri dishes (15 cm diam.). The dishes were placed within plastic containers (170 L capacity) with $200 \mathrm{~mL}$ of sterile water plus $2 \mathrm{~mL}$ of glycerol, with the internal temperature and relative humid around $25^{\circ} \mathrm{C}$ and $85 \%$, respectively (Castañeda-Ruiz 2005). The leaf litter was examined at regular intervals for the presence of microfungi. Mounts were prepared in polyvinyl alcohol-glycerol $(8 \mathrm{~g}$ in $100 \mathrm{~mL}$ of water, plus $5 \mathrm{~mL}$ of glycerol) and measurements made at a magnification of $x$ 1000. All materials have been deposited in the Herbarium of Universidade Estadual de Feira de Santana (HUEFS).

\section{Results and discussion}

From the leaf litter collected in the semi-arid regions investigated, nine species of Stachybotrys were found: Stachybotrys bisbyi, S. chartarum, S. globosa, S. kampalensis, S. longispora, S. nilagirica Subram., S. nephrospora, S. parvispora and S. verrucispora. Of these, $S$. nilagirica is a new record for Brazil. All these listed species are described, illustrated and commented. A key for all Stachybotrys species recorded from semiarid region is included.

Stachybotrys bisbyi (Sriniv.) G.L. Barron, Mycologia 56:315. 1964. $\equiv$ Hyalostachybotrys bisbyi Sriniv, J. Indian bot. Soc. 37: 340. 1958.

Figure 1

Conidiophores erect, straight or flexuous, rarely branched, septate, smooth, rarely verrucose, median region pale brown, apex hyaline, 108-315 × 5-9 $\mu \mathrm{m}$; conidiogenous cells monophialidic, terminal, discrete, clustered at the apex of conidiophores determinate, ellipsoidal, smooth, hyaline 12-15 × 2-3 $\mu \mathrm{m}$; conidia, ellipsoidal, aggregated in slimy masses, smooth, guttulate, hyaline, $10-15 \times 3-5 \mu \mathrm{m}$.

Specimens examined: BRAZIL. BAHIA: Santa Terezinha, on decaying petiole of an unidentified dicotyledonous plant, 03-XI-2005, M.F.O. Marques s.n. (HUEFS105743).

Distribution: Brazil (Marques et al. 2007), Canada, Egypt, India, Mozambique, (Jong \& Davis 1976), China, Philippines (Whitton et al. 2001), Cuba (Mercado-Sierra et al. 1997), Italy (Piontelli et al. 1999), Slovak Republic (Kubátová 1994), Japan (Matsushima 1975), Papua New Guinea (Matsushima 1971), South Africa, USA (Morgan-Jones 1977).

Stachybotrys bisbyi, S. bambusicola Rifai and $S$. palmijunci Rifai are the only species with hyaline conidia in white slimy masses; however, S. bisbyi differs by conidiogenous cell without percurrent proliferation, a character observed in the last two species. Of the other similar species $S$. bambusicola has smaller conidia while those of S. palmijunci are wider (Matsushima 1980, Piontelli et al.1999). These species appear to have a restricted geographic distribution and are found on several substrates such as stems, leaves and cortex (Piontelli et al. 1999). The conidiophores observed on the Brazilian 


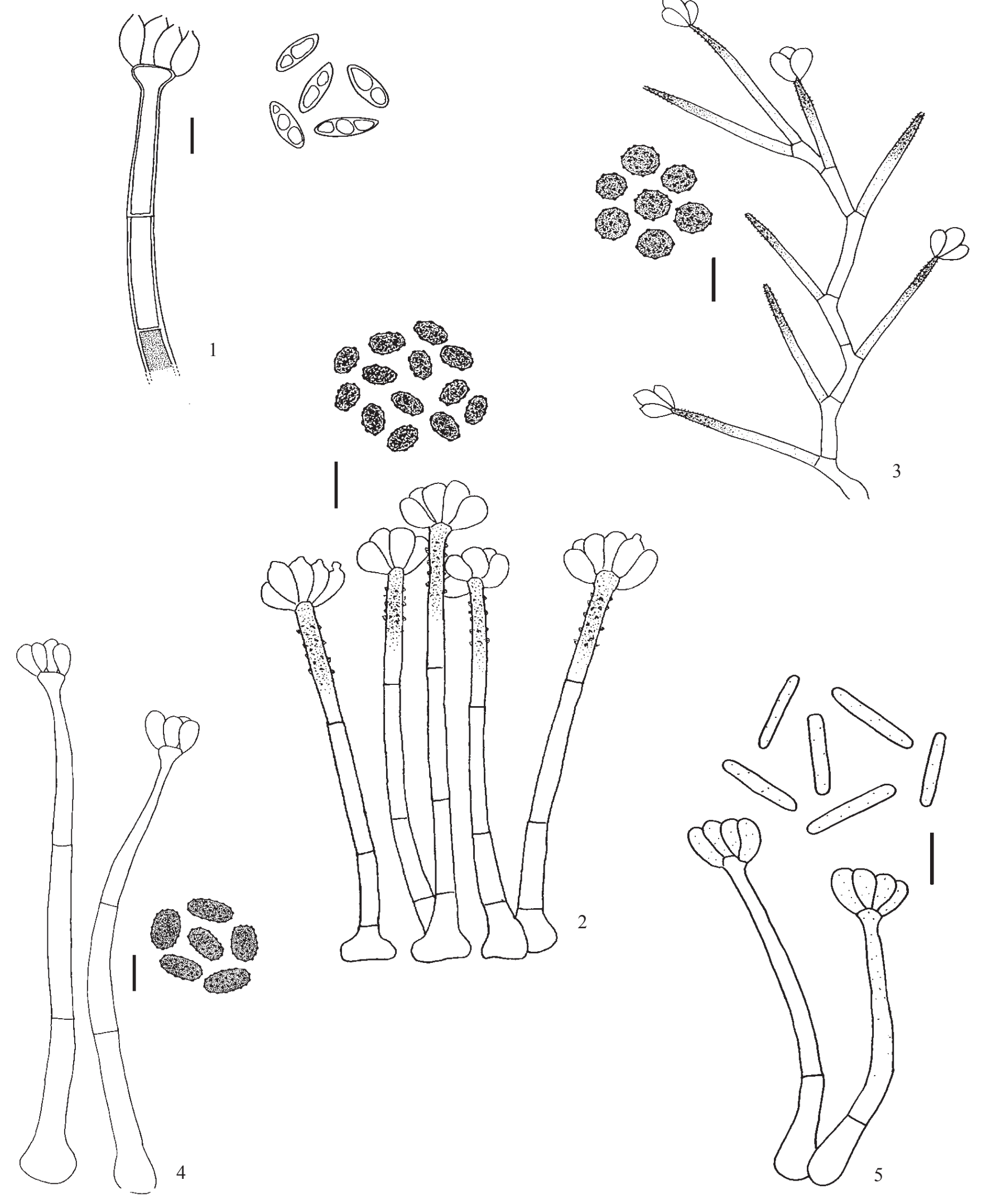

Figures 1-5. Conidiophores, conidiogenous cells and conidia. 1. Stachybotrys bisbyi. 2. S. chartarum. 3. S. globosa. 4. S. kampalensis. 5. S. longispora. $\mathrm{Bar}=10 \mu \mathrm{m}$. 
material are wider than those reported for the species (Jong \& Davis 1976, Kubátová 1994, Mercado-Sierra et al. 1997, Piontelli et al. 1999). The species, despite a relatively worldwide geographic distribution, was not reported in South America before Marques et al. (2007).

Stachybotrys chartarum (Ehrenb.) S. Hughes, Can. J. Bot. 36: 812. 1958. $\equiv$ Stilbospora chartarum Ehrenb., Sylv. mycol. berol. (Berlin) 9: 21 (1818). 三 Oidium chartarum Link, in Willdenow, Willd., Sp. pl., Edn 4 6(1): 124 (1824). $\equiv$ Oospora chartarum (Ehrenb.) Wallr., Fl. crypt. Germ. (Nürnberg) 2: 184 (1833).

Figure 2

Conidiophores erect, straight or flexuous, unbranched, septate, smooth, hyaline at the base, verrucose and light brown at the apex, $28-100 \times 3-4.5 \mu \mathrm{m}$; conidiogenous cells monophialidic, terminal, discrete, clustered at the apex of conidiophores, determinate, clavate, smooth, 7-12 × 3-5 $\mu \mathrm{m}$; conidia ellipsoidal, ridged or banded surface, aggregated in slimy masses, verrucose, black, 6.5-10 × 3-5.5 $\mu \mathrm{m}$.

Specimen examined: BRAZIL. BAHIA: Morro do Chapéu, on dead leaves of an unidentified dicotyledonous plant, 29-VI-2007, T.S. Santa Izabel s.n. (HUEFS131813); Macajuba, on dead leaves of Arrabidaea cinerea Bureau ex K. Schum., 15-IV-2000, L.F.P. Gusmão s.n. (HUEFS42748); Rio de Contas, on dead leaves of Stachytarpheta crassifolia Schrad., 20-IV-2001, L.F.P. Gusmão s.n. (HUEFS56581); Pernambuco: Buíque, on dead leaves of an unidentified dicotyledonous plant, 16-X-2007, T. S. Santa Izabel s.n. (HUEFS131814).

Distribution: Cosmopolitan (Jong \& Davis 1976).

The dimensions of the taxonomic characters are in agreement with other authors (Ellis 1971, Jong \& Davis 1976, Matsushima 1975, Whitton et al. 2001). The main characteristic of the species is the morphology and roughness of the conidia. S. chartarum is a cellulolytic saprophyte frequently isolated from paper, wallpaper and gypsum wallboard in buildings or residences that have experienced water damage (Li \& Yang 2005). This species has a broad morphological variability in culture and is the most common species collected around the world (Jong \& Davis 1976).

Stachybotrys globosa P. C. Misra \& S. K. Srivast., Trans. Br. Mycol. Soc. 78: 556. 1982.

Figure 3

Conidiophores macronematous, mononematous, erect, straight, sympodially branched, septate, smooth, hyaline at the base, echinulate and pale gray at the apex, 108-185 $\times 2-3.5 \mu \mathrm{m}$; conidiogenous cells monophialidic, terminal, discrete, clustered at the apex of conidiophores, determinate, obovate, smooth, hyaline, 4.5-8.5 $\times$ 2.5-4.5 $\mu \mathrm{m}$; conidia solitary 0 -septate, spherical, aggregated in slimy masses, verrucose, dark brown, 4.5-7.5 $\mu \mathrm{m}$ diam.

Specimen examined: BRAZIL. Rio Grande Do NorTE: Seridó, on dead leaves of an unidentified plant, 18-IV-2006, S. M. Leão-Ferreira s.n (HUEFS105746); BAHIA: Pilão Arcado, on dead fruit of an unidentified dicotyledonous plant, 08-III-2007, A.C.R. Cruz s.n. (HUEFS125380); on dead leaves of an unidentified dicotyledonous plant, 07-III-2007, A.C.R Cruz s.n. (HUEFS125381).

Distribution: Brazil (Leão-Ferreira et al. 2008), India (Misra \& Srivastava 1982).

Among the species circumscribed in the genus, $S$. microspora (B. Marthur \& Sankina) Jong \& Davis and S. nilagirica Subram. are closest to $S$. globosa in having spherical or globose conidia (Misra \& Srivastava 1982). However these species, differ from $S$. globosa by pattern of branching conidiophores and size of conidia (Pinruan et al. 2004). The examined specimen has conidiophores larger than those described in the literature (Misra \& Srivastava 1982, Pinruan et al. 2004). S. globosa has a restricted geographic distribution and was not found in the American Continent before Leão-Ferreira et al. (2008).

Stachybotrys kampalensis Hansf. Proc. Linn. Soc. London 155: 45. 1943.

Figure 4

Conidiophores erect, straight or flexuous, unbranched, septate, smooth, hyaline, 127.5-155 $\times 7.5-10 \mu \mathrm{m}$; conidiogenous cells monophialidic, terminal, discrete, clustered at the apex of conidiophores, determinate, elliptic to clavate, smooth, hyaline 8-12 $\times$ 6-7 $\mu \mathrm{m}$; conidia ellipsoidal, aggregated in slimy masses, verrucose at maturity, dark olivaceous to black, 10-12 $\times 5-7 \mu \mathrm{m}$.

Specimen examined: BRAZIL. BAHIA: Santa Terezinha, on dead leaves of an unidentified dicotyledonous plant 09-XII-2005, M.F.O. Marques s.n. (HUEFS107200).

Distribution: Australia, India, USA, formerly USSR (Farr \& Rossman 2008), Brazil (Marques et al. 2007), China (Wong \& Hyde 2001), Cuba (Mercado-Sierra et al. 1997), Japan (Matsushima 1975), Papua New Guinea (Matsushima 1971). 
Stachybotrys kampalensis is found in tropical and subtropical areas, and is characterized by smooth conidiophores and verrucose conidia (Mercado-Sierra et al. 1997). Of the related species, S. microspora and $S$. parvispora have smaller conidia those of $S$. kampalensis (Mercado-Sierra et al. 1997). The measurements of conidiophores and conidia are smaller than those reported by Matsushima (1971), Ellis (1971) and Mercado-Sierra et al. (1997). The species was not found in South America before Marques et al. (2007).

Stachybotrys longispora Matsush. Icon. microfung. Matsush. lect. (Kobe): 145.1975.

Figure 5

Conidiophores erect, straight or flexuous, unbranched, septate, smooth, hyaline or rarely subhyaline at the apex, 53-83 $\times 4-5 \mu \mathrm{m}$; conidiogenous cells monophialidic, terminal, discrete, clustered at the apex of conidiophores, determinate, obovate, smooth, subhyaline, 6-9 × 2-3 $\mu \mathrm{m}$; conidia solitary, 0 -septate, cylindrical, rounded at the ends, aggregated in slimy masses, smooth, subhyaline, 12-15 × 1.8-2.4 $\mu \mathrm{m}$.

Specimens examined: BRAZIL. BAHIA: Santa Terezinha, on dead leaves of Clusia melchiori Gleason, 29-II-2006, F.R. Barbosa s.n. (HUEFS122232); 27-IV-2006, F.R. Barbosa s.n. (HUEFS123372); 28-VI-2006, F.R. Barbosa s.n. (HUEFS125438).

Distribution: Brazil (Castañeda-Ruiz et al. 2003), Cuba (Mercado-Sierra \& Mena-Portales 1988), Japan (Matsushima 1975).

Stachybotrys longispora was described from Japan on dead leaves of Ilicis latifoliae (Matsushima 1975). The specimens examined present larger conidiophores and smaller conidiogenous cells than other literature examined (Matsushima 1975, Mercado-Sierra \& MenaPortales 1988). Stachybotrys longispora is related to $S$. eucylindrospora $\mathrm{Li}$, however, the latter species has conidia with ornaments or striations (Li 2007). Stachybotrys yunnanensis has cylindrical or subcylindrical conidia, but they are wider than those of $S$. longispora (Kong 1997). In Brazil, the species was found by CastañedaRuiz et al. (2003) on rotten leaves in Northeast region at Paraiba State.

Stachybotrys nephrospora Hansf., Proc. Linn. Soc. London 155: 45. 1943.

Figure 6

Conidiophores erect, straight or flexuous, occasionally branched, septate, verrucose and subhyaline at the base, smooth and hyaline at the apex, up to $320 \times$
3-4 $\mu \mathrm{m}$; conidiogenous cells monophialidic, terminal, discrete, clustered at the apex of conidiophores, determinate, hyaline at the base, brown at the apex, 9-12 $\times 5-6 \mu \mathrm{m}$; conidia reniform, aggregated in slimy masses, verrucose, black, 8.5-11 $\times 5-7 \mu \mathrm{m}$.

Specimens examined: BRAZIL. CeArÁ: Crato, on dead leaves of an unidentified dicotyledonous plant, 10-VII-2007, T. S. Santa Izabel s.n. (HUEFS131815); BAHIA: Jacobina, on dead leaves of Asteraceae, 06-VIII-2001, L.F.P Gusmão S.n. (HUEFS56643).

Distribution: Brazil (Barbosa et al. 2008), Canada, Cuba, Nigeria, Pakistan (Mercado-Sierra et al. 1997), India, Jamaica, Sierra Leone (Ellis 1971), Japan, Uganda (Jong \& Davis 1976), New Zealand (Whitton et al. 2001), Papua New Guinea (Matsushima 1971), Thailand, USA (Farr \& Rossman 2008).

The dimensions of the taxonomic characters are in agreement with the measurement given in literature (Ellis 1971, Matsushima 1975, Jong \& Davis 1976, Whitton et al. 2001), except for dimensions of the conidia that are smaller. The main characteristics of the species are the morphology of branched conidiophores and reniform conidia. Six species of Stachybotrys are known to produce reniform conidia (Whitton et al. 2001). Stachybotrys reniverrucosa Whitton, McKenzie \& K. D. Hyde has unbranched conidiophores and conidia are larger than those of S. nephospora (Whitton et al. 2001); S. renispora P. C. Misra, S. renisporoides K. G. Karand., S. M. Kulk. $\&$ Patw. and S. proliferata K. G. Karand., S. M. Kulk. \& Patw. have smooth and smaller conidia (Misra 1976, Whitton et al. 2001). Stachybotrys oenanthes M. B. Ellis has verrucose conidia as in $S$. nephrospora, however, the conidiophores are unbranched and smaller (Ellis 1976). The species was not reported from South America, before Gusmão et al. (2006).

Stachybotrys nilagirica Subram. Proc. Indian Acad. Sci., P1. Sci. 46: 331. 1957.

Figure 7

Conidiophores erect, straight or flexuous, septate, unbranched, smooth, hyaline at the base, olive gray at the apex, 225-300 $\times 13.5-16.5 \mu \mathrm{m}$; conidiogenous cells monophialidic, terminal, discrete, clustered at the apex of conidiophores, determinate, obovate, smooth, subhyaline, 13.5-16.5 × 6-9 $\mu \mathrm{m}$; conidia spherical, tuberculate, aggregated in slimy masses, dark olive gray to black, 23.5-25.5 $\mu \mathrm{m}$ diam.

Specimen examined: BRAZIL. BAHIA: Santa Terezinha, on dead leaves of an unidentified dicotyledonous plant, 20-XII-2005, A. C. R. Cruz s.n. (HUEFS105744). 

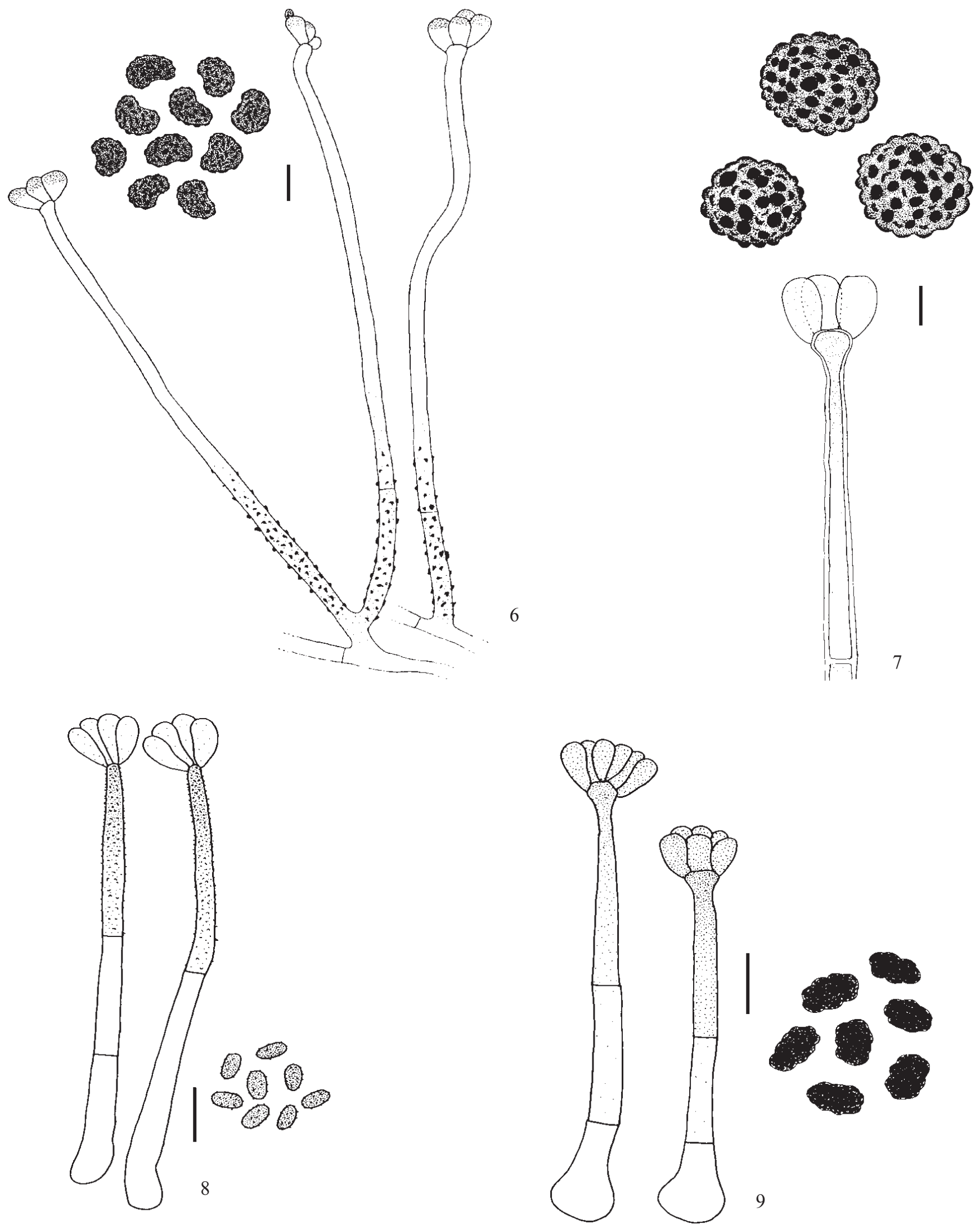

Figures 6-9. Conidiophores, conidiogenous cells and conidia. 6. Stachybotrys nephrospora. 7. S. nilagirica. 8. S. parvispora. 9. $S$. verrucispora. $\mathrm{Bar}=10 \mu \mathrm{m}$. 
Distribution: Cuba(Mercado-Sierra et al. 1997), India (Subramanian 1957), Japan (Matsushima 1975), New Zealand (Hughes 1978), Peru (Matsushima 1993).

The material observed is in agreement with the descriptions given in the literature (Subramanian 1957, Matsushima 1975, Hughes 1978, Mercado-Sierra et al. 1997). However, the Brazilian specimen has two or three conidiogenous cells clustered in a fascicle, differing from the other specimens that display four to six conidiogenous cells. Stachybotrys sphaerospora Morgan-Jones \& R.C. Sinclair has spherical conidia similar to $S$. nilagirica, however, it differs by smaller conidia and branched conidiophores (Morgan-Jones \& Sinclair 1980).

Stachybotrys parvispora S. Hughes, Mycol. Pap. 48:74. 1952.

Figure 8

Conidiophores erect, straight or flexuous, solitary or in groups, unbranched, septate, smooth, rarely verrucose at the apex, hyaline, 75-128 $\times 3-4.5 \mu \mathrm{m}$; conidiogenous cells monophialidic, terminal, discrete, clustered at the apex of conidiophores, determinate, clavate to ellipsoidal, smooth, hyaline, 7-9 × 3-4 $\mu$ m; conidia ellipsoidal, aggregated in slimy masses, finely verrucose, dark brown, 4-6 $\times 3-4.5 \mu \mathrm{m}$.

Specimens examined: BRAZIL. BAHIA: Santa Terezinha, on dead leaves of Clusia melchiorii Gleason, 29-XII-05, F.R. Barbosa s.n. (HUEFS114762); on dead leaves of Clusia nemorosa G.F.W. Meyer, 18-X-05, F.R. Barbosa s.n. (HUEFS105742).

Distribution: Brazil (Barbosa et al. 2009), China, Thailand (Farr \& Rossman 2008), Colombia (Goos 1997), Congo, Malaysia, Sierra-Leone (Ellis 1971), Cook Islands, Solomon Islands, New Caledonia (McKenzie 1991), Cuba (Mercado-Sierra et al. 1997), Ghana (Hughes 1952), Ivory Coast (Rambelli et al. 1981), Japan (Matsushima 1985), New Zealand (GBIF 2008), Spain, Zaire (Stalpers 2003).
Stachybotrys parvispora was originally described by Hughes (1952) on dead leaves from Gold Coast in tropical Africa. Stachybotrys parvispora is related with S. kampalensis, however, the latter species has larger conidia (Jong \& Davis 1976). The characteristics of specimens examined are in accordance with previous descriptions (Jong \& Davis 1976, McKenzie 1991, Goos 1997, Mercado-Sierra et al. 1997).

Stachybotrys verrucispora Matsush. Matsush. Mycol. Mem. 4: 18. 1985.

Figure 9

Conidiophores erect, straight or flexuous, solitary, unbranched, smooth, hyaline at the base, pale gray at the apex, 58-70 $\times$ 4.5-6.5 $\mu \mathrm{m}$; conidiogenous cells monophialidic, terminal, discrete, clustered at the apex of conidiophores, determinate, clavate, smooth, pale gray to pale brown, $7.5-10.5 \times 3-3.5 \mu \mathrm{m}$; conidia broadly ellipsoidal, aggregated in slimy masses, verrucose, black, 7-10.5 × 4.5-6 $\mu \mathrm{m}$.

Specimens examined: BRAZIL. Rio Grande DO NoRTE: Seridó, on dead leaves of an unidentified dicotyledonous plant, 26-IV-2006, S. M. Leão-Ferreira s.n. (HUEFS105764).

Distribution: Brazil (Leão-Ferreira et al. 2008), Brunei, Philippines (Whitton et al. 2001), Palau, Seychelles Islands (Matsushima 1985).

The species was collected for the first time on a petiole of Cyatheae sp. (Matsushima 1985). Stachybotrys waitakere Whitton, McKenzie \& K. D. Hyde has verrucose and broadly ellipsoid conidia similar to $S$. verrucispora, however, it differs by possessing a rounded base or broad truncate papilla on the conidia (Whitton et al. 2001). The conidia and conidiophores of examined material are smaller than reported in the literature (Matsushima 1985, Whitton et al. 2001, Pinruan et al. 2004). Stachybotrys verrucispora was first reported in South America by Leão-Ferreira et al. (2008).

Key to species of Stachybotrys found in semi-arid region of Brazil.

1. Mature conidia hyaline S. bisbyi

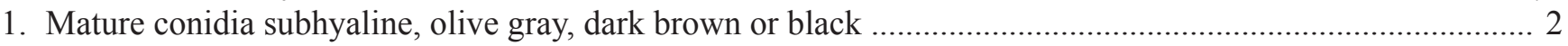

2. Mature conidia smooth .......................................................................................................... S. longispora

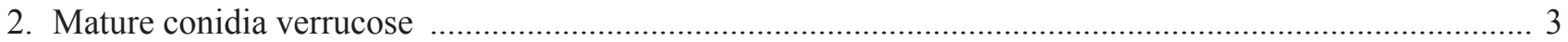

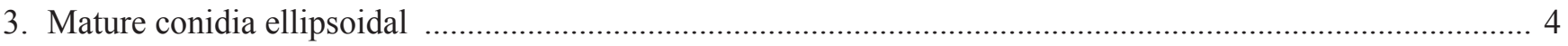

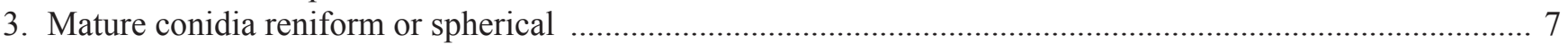

4. Mature conidia $10-12 \mu \mathrm{m}$ in length S. kampalensis

4. Mature conidia up to $10 \mu \mathrm{m}$ in length 
5. Mature conidia less than $6 \mu \mathrm{m}$ in length S. parvispora

5. Mature conidia more than $6 \mu \mathrm{m}$ in length 6

6. Conidiophores verrucose and light brown at the apex ......................................................... S. chartarum

6. Conidiophores smooth and pale gray at the apex ................................................................. S. verrucispora

7. Mature conidia reniform S. nephospora

7. Mature conidia spherical S. globosa

8. Conidiophores sympodially branched, conidia 4.5-7.5 $\mu \mathrm{m}$ diam. S. nilagirica

8. Conidiophores unbranched, conidia 23.5-25.5 $\mu \mathrm{m}$ diam.

ELLIS, M.B. 1976. More dematiaceous Hyphomycetes. Commonwealth Mycological Institute, Kew.

Acknowledgements - The authors thank the "Programa de Pós-graduação em Botânica - PPGBot/UEFS"; F.R. Barbosa, M.F. O. Marques and S.M. Leão-Ferreira thank Capes and T. S. Santa Izabel thanks CNPq. A.C.R. Cruz and L.F.P. Gusmão extend thanks to Fapesb (Proc. APR071/2007) and PPBIO (Research Program of Biodiversity in the Semi-arid), respectively.

\section{References}

BATISTA, A.C. \& UPADHYAY, H.P. 1965. Soil fungi from Northeast Brazil - I. Atas do Instituto de Micologia, Universidade Federal de Pernambuco. Recife, v.2, p.319-350.

BARBOSA, F.R, GUSMÃO, L.F.P, BARBOSA, F.F. 2008. Fungos anamórficos (Hyphomycetes) no Semi-árido do Estado da Bahia, Brasil. Acta Botanica Brasilica 22:2936.

BARBOSA, F.R, MAIA, L.C, GUSMÃO, L.F.P. 2009. Novos registros de Hyphomycetes decompositores para o Estado da Bahia, Brasil. Acta Botanica Brasilica 23:323-329.

CARMICHAEL, J.W., KENDRICK, W.B., CONNERS, I.L. \& SIGLER, L. 1980. Genera of Hyphomycetes. University of Alberta Press, Edmonton.

CASTAÑEDA-RUIZ, R.F. 2005. Metodología en el estudio de los hongos anamorfos. In Anais do V Congresso Latino Americano de Micologia, Associação Latino Americana de Micologia, Brasília, p.182-183.

CASTAÑEDA-RUIZ, R.F., GUARRO, J., VELAZQUEZNOA, S. \& GENE, J. 2003. A new species of Minimelanolocus and some hyphomycete records from rain forests in Brazil. Mycotaxon 85:231-239.

CORDA, A.C.I. 1837. Icones Fungorum hucusque cognitorum. Published by the author. Prague, v.1.

DEARBORN, D.G., YIKE, I., SORENSON, W.G., MILLER, M.J. \& ETZEL, R.A. 1999. Overview of investigations into pulmonary hemorrhage among infants in Cleveland, Ohio. Environmental Health Perspectives 107:495-499.

ELIDEMIR, O., COLASURDO, G.N., ROSSMANN, S.N. \& FAN, L.L. 1999. Isolation of Stachybotrys from the lung of a child with Stachybotrys chartarum and related species pulmonary hemosiderosis. Pediatrics 102:964-966.

ELLIS, M.B. 1971. Dematiaceous Hyphomycetes. Commonwealth Mycological Institute, Kew.
FARR, D.F. \& ROSSMAN, A.Y. Fungal Databases. 2008. Systematic Mycology and Microbiology Laboratory, ARS, USDA. http://nt.ars-grin.gov/fungaldatabases (accessed 2008 Nov 10).

GBIF - Global Biodiversity Information Facility. 2008. http://www.gbif.org (accessed 2008 Nov 6).

GOOS, R.D. 1997. Fungi of Barro Colorado Island, adjacent Panama, and the Cali region of Colombia. Mycotaxon 64:375-383.

GUSMÃO, L.F.P., BARBOSA, F.R. \& BARBOSA, F.F. 2006. Fungos Conidiais. In Diversidade e caracterização dos fungos do semi-árido (L.F.P. Gusmão \& L.C. Maia, eds.). Associação Plantas do Nordeste, Recife, v.2, p.161-201.

HAUGLAND, R.A., VESPER, S.J. \& HARMON, S.M. 2001. Phylogenetic relationships of Memnoniella and Stachybotrys species and evaluation of morphological features for Memnoniella species identification. Mycologia 93:54-65.

HUGHES, S.J. 1952. Fungi from the Gold Coast I. Mycological Papers 8:1-91.

HUGHES, S.J. 1958. Revisiones Hyphomycetum aliquot cum appendice de nominibus rejiciendis. Canadian Journal of Botany 36:727-836.

HUGHES, S.J. 1978. New Zealand fungi. 25. Miscellaneous species. New Zealand Journal of Botany 6:311-370.

JONG, S.C. \& DAVIS, E.E. 1976. Contribution to the knowledge of Stachybotrys and Memnoniella in culture. Mycotaxon 3:409-486.

KONG, H.Z. 1997. Stachybotrys yunanensis sp. nov. and Neosartorya delicata sp. nov. isolated from Yunnan, China. Mycotaxon 62:427-433.

KUBATOVA, A. 1994. New records of micromycetes from Czech and Slovak Republics III. Acremonium furcatum, Gonatobotryum parasiticum, Stachybotrys bisbyi and Wardomyces inflatus. Czech Mycology. 47:151-158.

LEÃO-FERREIRA, S.M., CRUZ, A.C.R., CASTAÑEDARUIZ, R.F. \& GUSMÃO, L.F.P. 2008. Conidial fungi from the semi-arid Caatinga biome of Brazil. Brachysporiellina fecunda sp. nov. and some new records to Brazil, South America and Neotropica. Mycotaxon 104:309-312. 
LI, D.-W. 2007. Stachybotrys eucylindrospora, sp. nov. resulting from a re-examination of Stachybotrys cylindrospora. Mycologia 99:332-339.

LI, D.-W. \& YANG, C.S. 2005. Taxonomic history and current status of Stachybotrys chartarum and related species. Indoor Air 15:5-10.

MARQUES, M.F.O., BARBOSA, F.F., GUSMÃO, L.F.P, CASTAÑEDA-RUIZ, R.F. \& MAIA, L.C. 2007. Conidial fungi from the semi-arid Caatinga biome of Brazil. Cubasina microspora sp. nov., a note on C. albofusca and some records for South America. Mycotaxon 102:17-23.

MATSUSHIMA, T. 1971. Microfungi of the Solomon Islands and Papua-New Guinea. Published by the author, Kobe.

MATSUSHIMA, T. 1975. Icones Microfungorum a Matsushima Lectorum. Published by the author, Kobe.

MATSUSHIMA, T. 1980. Matsushima Mycological Memoirs no 1. Matsushima Fungus Collection, Kobe.

MATSUSHIMA, T. 1985. Matsushima Mycological Memoirs no 4. Matsushima Fungus Collection, Kobe.

MATSUSHIMA, T. 1993. Matsushima Mycological Memoirs no 7. Matsushima Fungus Collection, Kobe.

MCKENZIE, E.H.C. 1991. Dematiaceous hyphomycetes on Freycinetia (Pandanaceae). 1. Stachybotrys. Mycotaxon 61:179-188.

MERCADO-SIERRA, A. \& MENA-PORTALES, J. 1988. Nuevos o raros hifomicetes de Cuba. V. Especies de Stachybotrys. Acta Botánica Cubana 55:1-8.

MERCADO-SIERRA, A., HOLUBOVÁ-JECHOVÁ, V. \& MENA-PORTALES, J. 1997. Hifomicetes demaciáceos de Cuba Enteroblásticos. Museo Regionale di Scienze Naturali, Monografie XXIII, Torino.

MISRA, P.C. 1976. Stachybotrys renispora sp. nov. Mycotaxon 4:161-162.
MISRA, P.C. \& SRIVASTAVA, S.K. 1982. Two undescribed Stachybotrys species from Índia. Transactions of the British Mycological Society 78:556-559.

MORGAN-JONES, G. 1977. Fungi of Alabama. VI. Dematiaceous hyphomycetes. Journal Alabama Academic Science 48:26-41.

MORGAN-JONES, G. \& SINCLAIR, R.C. 1980. Notes on hyphomycetes. XXXIII. Stachybotrys sphaerospora sp. nov. from South Africa. Mycotaxon 10:372-374.

PINRUAN, U., MCKENZIE, E.H.C., JONES, E.B.G. \& HYDE, K.D. 2004. Two new species of Stachybotrys, and a key to the genus. Fungal Diversity 17:145-157.

PIONTELLI, E., PICCO, A.M. \& MARINELLA, R. 1999. Algunos hyphomycetes dematiaceos epifitos del norte de Italia. Boletin Micológico 14:101-108.

RAMBELLI, A., ONOFRI, S. \& LUNGHINI, D. 1981. New dematiaceous hyphomycetes from Ivory Coast forest litter. Transactions of the British Mycological Society 76:53-58.

SMITH, G. 1962. Some new and interesting species of micro-fungi. III. Transactions of the British Mycological Society 45:387-394.

STALPERS, J. 2003. Filamentous fungi database. CBS - Centraalbureau voor Schimmelcultures. http://www. cbs.knaw.nl/ (accessed 2008 Mar 25).

SUBRAMANIAN, C.V. 1957. Hyphomycetes IV. Proceedings of the Indian National Sciences Academy 46:324-335.

WHITTON, S.R., MCKENZIE, E.H.C. \& HYDE, K.D. 2001. Microfungi on the Pandanaceae: Stachybotrys, with three new species. New Zealand Journal of Botany 39:489-499.

WONG, M.K.M. \& HYDE, K.D. 2001. Diversity of fungi on six species of Gramineae and one species of Cyperaceae in Hong Kong. Mycological Research 105:1485-1491. 